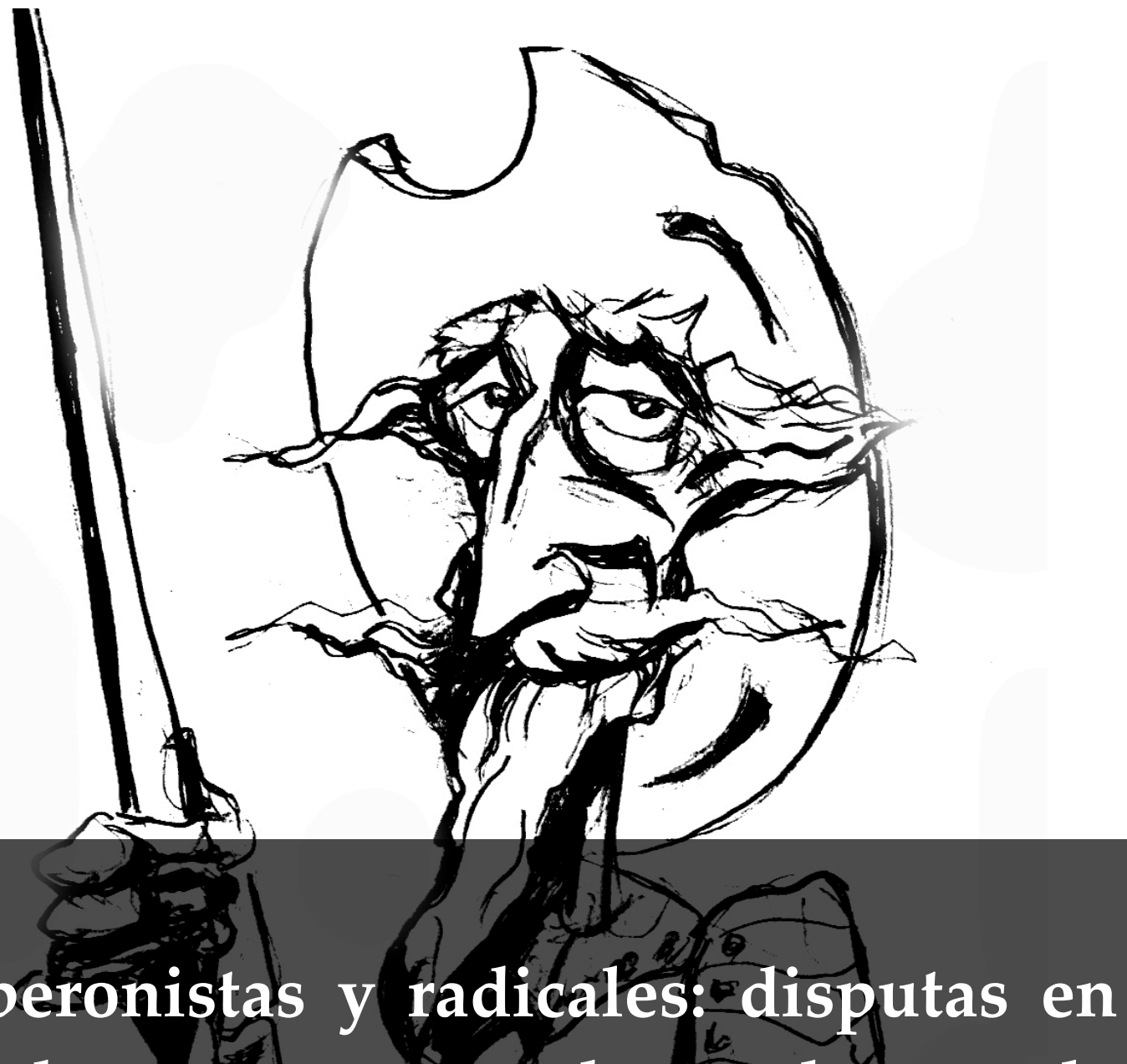

Entre peronistas y radicales: disputas en torno al monumento/al gauchó en la provincia de Buenos Alires, 1947-1948

[Matías Emiliano Casas] 


\title{
Entre peronistas y radicales: disputas en torno al monumento al gaucho en la provincia de Buenos Aires, 1947-1948*
}

\author{
Between Peronists and Radicals: Disputes over the Monument to the Gaucho \\ in Buenos Aires, 1947-1948
}

\section{MATÍAS EMILIANO CASAS}

\section{Resumen}

La utilización política de la figura del gaucho que se había revitalizado con intensidad a finales de los años treinta- encontró un nuevo capítulo en los debates legislativos bonaerenses acontecidos entre 1947 y 1948. El tutelaje sobre lo gauchesco que había ostentado el sector conservador a partir de la institución del Día de la Tradición en 1939, entre otras intervenciones, se vio desafiada por la emergencia del peronismo. Ante la progresiva identificación de lo criollo con Juan Perón, los legisladores radicales bonaerense concibieron el proyecto de emplazar un monumento al gaucho para confirmar la potestad radical sobre lo "genuinamente argentino".

\section{Palabras clave}

Gaucho - peronismo - radicalismo - tradición criollismo

\begin{abstract}
The political use of the gaucho, which was revitalized with intensity in the thirties, has founded a new chapter in the Buenos Aires legislative debates between 1947 and 1948. The conservative politicians have boasted tutelage over the gaucho since the institution of the "Día de la Tradición" in 1939. However, the emergence of Peronism challenged that relationship. Against the progressive identification between Juan Perón and the creole, the legislators of the radical party presented a project to build a monument to the gaucho. Thus, they were disputing the guardianship of the "argentinidad".
\end{abstract}

\section{Key words}

Gaucho - Peronism - Radicalism - tradition criollismo

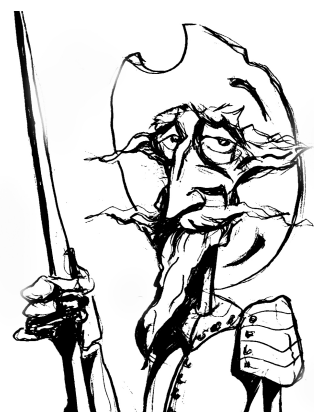

Recibido con pedido de publicación el 10 de diciembre de 2015

Aceptado para su publicación el 23 de febrero de 2016

Versión definitiva recibida el 9 de junio de 2016

Matías Emiliano Casas, Universidad Nacional de Tres de Febrero, Consejo Nacional de Investigaciones Científicas y Técnicas, Argentina; e-mail: mecasas@untref.edu.ar

\footnotetext{
* Agradezco a los evaluadores de este artículo por sus valiosas intervenciones y sugerencias

Esta obra se publica bajo licencia Creative Commons. Atribución-NoComercial-CompartirIgual 4.0 Internacional

Casas, Matías Emiliano "Entre peronistas y radicales: disputas en torno al monumento al gaucho en la provincia de Buenos Aires, 1947-1948”, Prohistoria, Año XIX, núm. 25, jun. 2016, pp. 53-78.
} 


\section{Introducción}

A partir de las reivindicaciones oficiales del gaucho a finales de la década del treinta, las asociaciones tradicionalistas que recreaban el escenario campero vivando al "arquetipo" de la identidad nacional encontraron un correlato en las intervenciones políticas que también se ocuparon de lo gauchesco en la misma perspectiva. La pretensión de consolidar la figura del gaucho como símbolo de la "argentinidad" fue confirmada por distintos sectores políticos. De hecho, su representación fue objeto de disputas partidarias que pretendieron dirimir su adhesión ideológica. Si bien la institución del Día de la Tradición en Buenos Aires, la fiesta gaucha por antonomasia, se había producido a mediados de 1939, bajo la órbita del conservador Manuel Fresco, los episodios que son analizados en este artículo dan cuenta de que el uso político del gaucho trascendió ampliamente a los gobiernos conservadores. El conjunto de medidas que involucró la celebración de la tradición campera permitía identificar la pervivencia -no sin modificaciones ni readaptaciones- de una política del gaucho. Es decir, desde la década del treinta se proyectaron una serie de disposiciones para consolidar espacios desde los cuales exaltarlo. Esas medidas oficiales no estuvieron exentas de contradicciones en torno a sus aplicaciones y financiamientos. La disputa política más álgida se desarrolló entre 1947 y 1948. Los radicales bonaerenses discutirían la ligazón entre el peronismo y lo criollo a partir del proyecto de construcción del monumento al gaucho. Un año después, por decreto del presidente Juan Perón, la Fiesta de la Tradición se nacionalizaba, y junto con ella, la figura del gaucho como referencia ineludible de la argentinidad.

Este trabajo se propone analizar las disputas partidarias por la apropiación del gaucho. Se considera que a partir de las operaciones que llevaron adelante representantes de la política, provincial y nacional, se ponía en evidencia la tensión en torno a una discusión simbólica que implicaba una necesaria reconstrucción de lo que se entendía por gauchesco. En efecto, los discursos que se pronunciaron en los debates legislativos interpelaban desde una perspectiva que iba más allá del gaucho y de la concreción del homenaje debatido. Es menester focalizar en esa dimensión abstracta que se conjugaba en las alocuciones y que pretendía perdurar, independientemente de la materialidad del monumento. En este estudio se reconoce una cadena de tutelajes sobre el gaucho que ostentaron, o se esforzaron por ostentar, políticos de distintos sectores.

Para el núcleo central de este artículo se consultaron los archivos de la Agrupación Bases de La Plata que había concebido el proyecto del Día de la Tradición. Su secretario general, Francisco Timpone, había sido concejal de esa ciudad en la coyuntura de la institución de la nueva efeméride a finales de la década del treinta. Su afición por la escritura y la organización de bibliotecas como lo demostraba su trayectoria en la agrupación platense- determinaron su 
continuidad como funcionario público. Desde 1946 ocupó el cargo de Director de Publicaciones y Prensa del Honorable Senado de Buenos Aires. Con motivo de la celebración de la Fiesta de la Tradición en 1948, año que, cómo se verá, resultaría clave para la trayectoria del nuevo festejo, se publicó una recopilación oficial auspiciada por el Senado y gestada por Timpone, titulada Día de la Tradición y monumento al gaucho, antecedentes legislativos.

Como el título anticipaba, la obra pretendía ser un compendio de los debates legislativos y, al mismo tiempo, constituir un homenaje al gaucho y la tradición campera. El tono laudatorio para rememorar su figura era confirmado por la carta introductoria del vice-gobernador Juan Bautista Machado quien solicitaba fundar en cada pueblo y ciudad un fortín gaucho para unir la República en un solo sentimiento tradicionalista. ${ }^{1}$ Además de las reseñas, la obra se completaba con una sección que transcribía conceptos varios sobre el gaucho y la tradición. Allí, las afirmaciones de escritores consagrados como Joaquín V. González se articulaban con poetas costumbristas para componer un cuadro ideal de los atributos gauchescos. La recopilación intercalaba expresiones que ayudaban a identificar al Gobierno de Perón con el fomento de las tradiciones y para eso se transcribían declaraciones del primer mandatario o de funcionarios- que promovían el cultivo del folklore y las costumbres vernáculas.

Más allá de revestir un carácter oficial, y de las operaciones remarcadas para exaltar la obra del peronismo en favor de las tradiciones nacionales, la publicación incorporó la totalidad de las intervenciones de legisladores sobre el monumento al gaucho. La pesquisa de ese acervo que permitía recuperar las voces adeptas y disidentes se complementó con la correspondencia interna de la agrupación citada y con diversas publicaciones periódicas de consumo masivo que se ocuparon del tópico en distintos números.

Si bien este trabajo puntualiza en los debates entre peronistas y radicales por la tutela del gaucho, y junto con él de la "tradición nacional", se advierte que esa práctica no constituía una novedad de esos años. Por el contrario, como se señalará aquí, los políticos conservadores expresaron una filiación directa con la reivindicación del gaucho, que se jactaba desde la institución del Día de la Tradición. El impulso a esa efeméride que celebraba cada 10 de noviembre en conmemoración a José Hernández, autor del Martín Fierro, había cristalizado la percepción, por parte de varios dirigentes provinciales, del "paternalismo" conservador sobre lo gauchesco. Claro que desde ese sector político se le asignaba una carga de sentido a esa reivindicación muy distinta a la que propondría el peronismo a mediados de la década del cuarenta.

\footnotetext{
${ }^{1}$ MACHADO, Juan Bautista, Carta preliminar, en TIMPONE, Francisco (comp.) Día de la Tradición y monumento al gaucho, antecedentes legislativos, Honorable Senado de Buenos Aires, La Plata, 1948, pp. 7-8.
} 
El peronismo, desde las políticas oficiales y desde la intervención de algunos de sus representantes, se esforzó por redefinir al gaucho. En esa redefinición, se desplazaba también el tutelaje hacia la figura de Juan Perón. La atención concentrada desde ese movimiento político no se circunscribió solo a la figura pampeana, por el contrario, el peronismo se interesó por abarcar un mosaico de manifestaciones culturales regionales y adherirse a ellas como parte constitutiva. Los estudios de Oscar Chamosa demostraron cómo las expresiones populares del noroeste argentino intensificaron su expansión hacia el centro del país a partir de la difusión del folklore. Entre otros tópicos, ese proceso evidenciaba también el interés del gobierno de Perón por sincretizar los caracteres iconográficos propios de esas culturas con simbolismos políticos, como se ejemplifica a partir del análisis de la Fiesta de la Zafra en Tucumán. ${ }^{2}$ Esa práctica no se remitió a las provincias del interior sino que la Fiesta de la Tradición en Buenos Aires, que se había concebido bajo la égida de los gobiernos conservadores, fue resignificada durante los años peronistas.

En otros estudios hemos advertido cómo las intervenciones peronistas en torno al gaucho y lo criollo se recibían -y retroalimentaban- desde las sociedades tradicionalistas que adoptaban una militancia política manifiesta. En algunos de esos grupos de "gauchos" caracterizados -particularmente demostrado en el Círculo Criollo El Rodeo de Moreno- que expresaron un resurgimiento exponencial en las zonas linderas a la Capital Federal durante la década del cuarenta, la figura de Perón resultó tan protagonista como la reivindicación del gaucho. ${ }^{3}$ Ezequiel Adamovsky se ha ocupado, en algunas investigaciones recientes, de la dimensión étnica de la narrativa criollista durante el peronismo. Sus estudios contribuyen -fundamentalmente a partir de la revisión de las publicaciones oficialistas El Laborista y Mundo Peronista- al análisis de la ampliación de sentido de "lo criollo" en tanto dispositivo de integración para los componentes no-blancos de la nacionalidad argentina. En sus trabajos se reseñan una serie de aproximaciones al criollismo, tanto de Perón como de representantes y funcionarios, para legitimar lo "genuinamente nacional" del movimiento. ${ }^{4}$

Entre las tentativas que se destacan allí se menciona el proyecto de ley de un senador peronista bonaerense para construir un monumento al gaucho en la provincia. No obstante, lejos de constituir un impulso más -de los numerosos

\footnotetext{
2 CHAMOSA, Oscar The argentine folklore movement. Sugar elites, criollo workers, and the politics of culture nationalism, 1900-1955, The University of Arizona Press, Arizona, 2010, pp. 157-182.

3 CASAS, Matías "Los gauchos de Perón. El Círculo Criollo El Rodeo, tradicionalistas y peronistas (1945-1955)" en Prácticas de oficio. Investigación y reflexión en Ciencias Sociales, núm. 15, agosto de 2015.

${ }^{4}$ ADAMOVSKY, Ezequiel "El criollismo en las luchas por la definición del origen y el color del ethnos argentino, 1945-1955" en Estudios Interdisciplinarios de América Latina y el Caribe, vol. 26, núm. 1, 2014, pp. 31-63.
} 
que se destacaron en el período- de ese sector político, la presentación de esa propuesta se podía leer como una "respuesta" de los políticos radicales a la progresiva ligazón entre el peronismo y la tradición nacional. En efecto, el proyecto fue presentado desde la bancada radical a partir de la intervención del senador Eduardo Molina. Como lo demostraron los discursos pronunciados, la proyección del monumento al gaucho contaba con una profusa trayectoria de idas y vueltas. En el artículo "Héroes patricios y gauchos rebeldes" de Alejandro Cattaruzza y Alejandro Eujanian, se mencionan sucintamente algunas de esas propuestas. Los autores señalan esas proyecciones en el marco de un tránsito más extenso que se vincula a la apropiación estatal de la figura del gaucho. ${ }^{5}$ Esa "propiedad" se discutiría con intensidad en los debates de 1947. En pos de comprender el bagaje que portaba el tópico para ese año, se revisitan aquí las problemáticas anteriores que habían obturado la concreción del homenaje.

\section{El monumento que no fue. Tensiones y desencuentros en los proyectos fallidos}

El origen del vocablo "monumento" proviene del latín monere cuya semántica indica "recordar, llamar la atención". ${ }^{6}$ Ese era el objetivo primario que persiguieron los impulsores y difusores de las iniciativas visibilizadas desde comienzos del siglo XX. Las proyecciones se insertaron en un contexto amplio de "democratización de las esculturas". Como señala Rodrigo Gutiérrez Viñuelas, en las primeras décadas de esa centuria comenzó a registrarse un desplazamiento del gusto por la monumentalización de los "próceres" hacia la presencia estatuaria de otras figuras y colectivos. ${ }^{7}$ Esa percepción, entre otros factores, fue habilitando la consideración de nuevas referencias para establecerse en el bronce.

Las propuestas para erigir un monumento al gaucho estuvieron fomentadas por distintos intereses y también por notorias diferencias en cuanto a lo que se quería recordar. De hecho, el gaucho fue atravesando mutaciones en orden a las funcionalidades coyunturales que se le fueron otorgando. Su figura se caracterizó por la labilidad para encarnar los atributos y desvalores más contradictorios. Es cierto que excede a los límites de este trabajo detenerse en las representaciones del gaucho, sin embargo es menester remarcar que las

\footnotetext{
${ }^{5}$ CATTARUZZA, Alejandro y EUJANIAN, Alejandro "Héroes patricios y gauchos rebeldes", en, CATTARUZZA, Alejandro y EUJANIAN, Alejandro Políticas de la historia, Argentina 18601960, Alianza Editorial, Madrid - Buenos Aires, 2003, pp. 217-262.

${ }^{6}$ PERSINO, María "Memoriales, museos, monumentos: la articulación de una memoria pública en la argentina posdictatorial", en Revista Iberoamericana, núm. 222, enero-marzo 2008, p.4.

7 GUTIÉRREZ VIÑUELAS, Rodrigo Monumento conmemorativo y espacio público en Iberoamérica, Grupo Anaya, Madrid, 2004, pp. 24-25.
} 
contradicciones en torno a su figura se reprodujeron en las discusiones sobre la construcción del monumento.

El bronce ausente a mediados de siglo, parecía constituir una carga simbólica para las voces que reivindicaban la figura del gaucho. En definitiva una serie de tensiones sobre los modelos propuestos, los financiamientos, los mentores de los proyectos -entre otras contrariedades- habían determinado el denominador común para todas las tentativas: su fracaso. Si bien es posible rastrear alguna mención en años anteriores, las propuestas que se visibilizaron con mayor intensidad se registran desde el contexto del centenario de la independencia argentina. En esa época, varios artículos publicados en la revista El Hogar cuestionaban la pertinencia de instalar un monumento al gaucho. En el transcurso de la segunda década del siglo $X X$, las expresiones que componían los niveles de disenso sobre los gauchos y la nacionalidad argentina parecían pronunciarse y reproducirse con mayor libertad en comparación con la década del cuarenta cuando el respaldo oficial a su figura ya se plasmaba en leyes provinciales y decretos presidenciales. De hecho, durante 1916, 1917 y 1918, se reprodujo un discurso opositor al homenaje desde las páginas de ese semanario.

Si bien no se encuentran datos concretos que permitan describir y analizar con mayor rigurosidad el aparente proyecto de construir y emplazar un monumento al gaucho en la Capital Federal, los artículos que refutaban esa intención otorgan una serie de precisiones. En el texto que expresa el primer cuestionamiento al posible monumento, la crítica se extendía hacia una evocación del pasado que, acorde a la editorial de El Hogar, se presentaba tergiversado por los "tradicionalistas" que se empeñaban en difundir "una Argentina pintoresca y falsa". En ese artículo se le atribuía a los dirigentes e intelectuales como Leopoldo Lugones la responsabilidad de la supuesta deformación del significado de patria: “Así estima la mayoría que 'patria' no es la realidad presente, la de todos los días, sino la legendaria pampa, el gaucho que ha creado la fantasía popular arrabalera y la milonga tristona." ${ }^{8}$ Por último, rechazaban la presencia en las noticias de temáticas como "el monumento al gaucho o la restauración de las zambas y chacareras santiagueñas".

La línea crítica continúo esbozando las razones de su oposición en el transcurso del año 1917. En enero apareció un artículo de José María Cao, el caricaturista español que había sido uno de los fundadores de la revista Caras y Caretas. Cao, junto con otros dos puntales de esa revista, Manuel Mayol y Eustaquio Pellicer, eran españoles inmigrantes que habían llegado a Buenos Aires a fines del siglo XIX. A su llegada, pusieron en práctica el bagaje cultural que les había aportado los vaivenes políticos entre monárquicos y republicanos españoles. La sátira política y el humor gráfico -novedosos para las

\footnotetext{
${ }^{8}$ El Hogar, 15 de septiembre de 1916.
} 
publicaciones bonaerenses- fueron sus recursos periodísticos principales. ${ }^{9}$ En ese sentido, el texto publicado en El Hogar se complementaba con una sugerente ilustración -Figura 1- que presentaba a un gaucho a caballo contemplando con pena sobre el pedestal del monumento la miseria y angustia de la gente que se recostaba contra sus paredes.

\section{FIGURA 1}

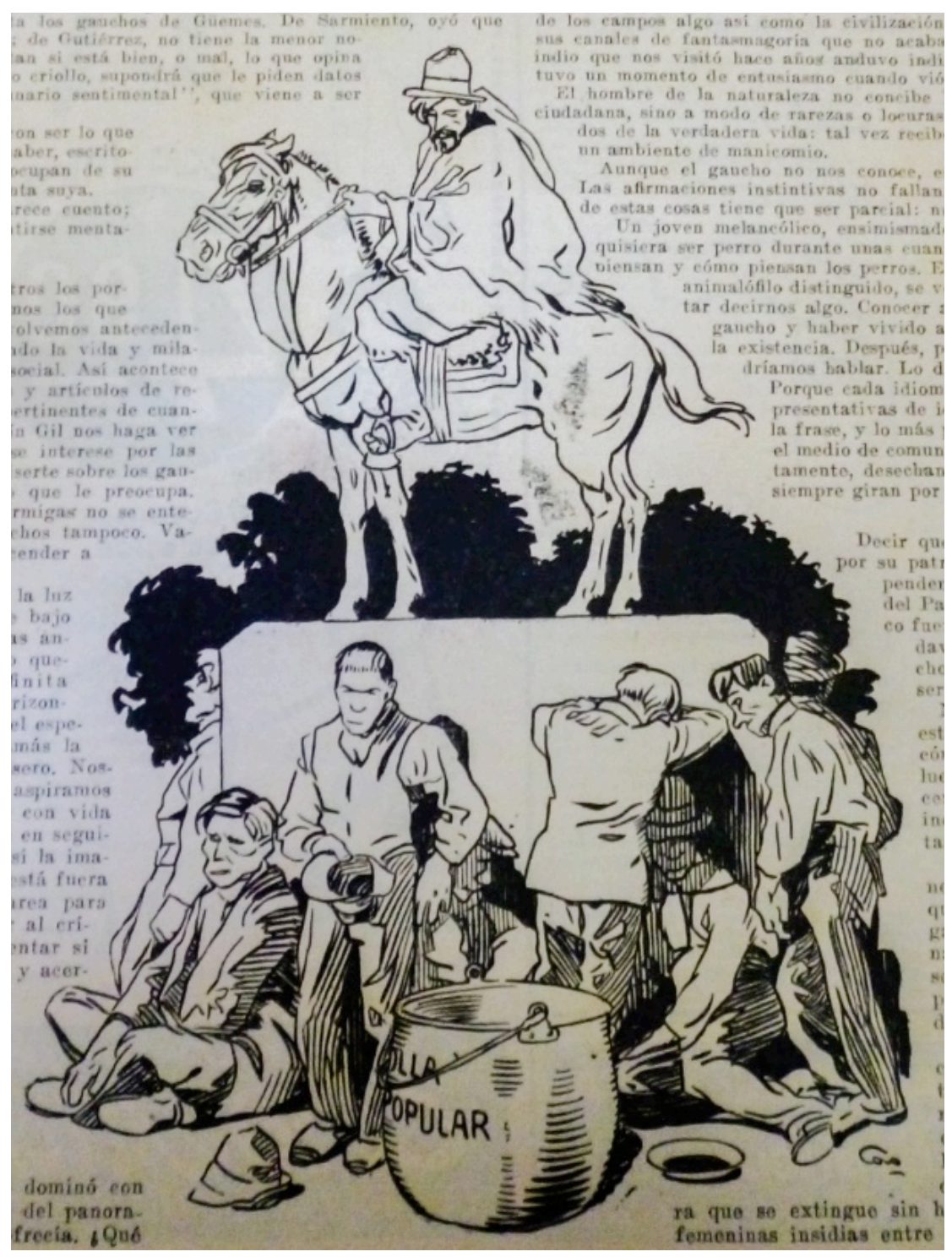

El Hogar, 19 de enero de 1917, p. 1.

El dibujo plasmaba la crítica de Cao. La exaltación del gaucho como un referente popular para la nación se tensaba directamente con la desatención a la clase trabajadora que era representada en condiciones miserables, en las que ni siquiera la olla popular parecía paliar la situación. En esa línea, se actualizaba el

\footnotetext{
9 SEOANE, María y SANTA MARÍA, Víctor La tragedia y la comedia de la Argentina: 1898-2008 [cien años de Caras y Caretas], Caras y Caretas, Buenos Aires, 2008, pp. 8-9.
} 
rechazo manifestado el año anterior en orden a publicar noticias de restituciones simbólicas. La ilustración permite inferir un cuestionamiento más profundo en relación a la emergencia de esas reivindicaciones como "escapatorias" a cuestiones que sí ameritarían una urgente atención. Al mismo tiempo, si bien el gaucho era colocado en el pedestal, su mirada parece asumir lazos de identificación con quienes reposan sobre su monumento. Incluso la indumentaria del homenajeado posibilita la interpretación de Cao en términos de compasión. El gaucho representado por el caricaturista desestima, desde su rostro, la pertinencia del bronce y desplaza el foco hacia los trabajadores afligidos.

En el artículo se cuestionaba: "Decir que el gaucho se merece la estatua por su patriotismo en la guerra de independencia, o en los esteros fronterizos del Paraguay es un concepto apriorístico, fuera de lógica". Es decir, Cao no solo desestimaba la participación del gaucho en el proceso independentista, tan remarcado décadas después por los legisladores bonaerenses, sino que refutaba su reconocimiento como "tronco étnico de una raza". El autor atribuía esa identificación a "dispositivos literarios de carente realidad."10 En la misma perspectiva se abordó la cuestión desde una editorial de 1918. Allí, se desestimaba al "idealizado cow-boy de nuestras pampas" en favor del "representante genuino de la raza autóctona de nuestra América, el indio". Además, la breve reseña criticaba los extremos en los que "panegiristas" y "detractores" caían al referirse a la figura del gaucho. En una suerte de búsqueda de neutralidad, el escrito no adhería a considerarlo ni "un dechado de virtudes" ni un "haragán, ladrón y criminal". ${ }^{11}$

El monumento al gaucho no se concretó en el contexto de los centenarios, y la ausencia de ese homenaje se retomó en algunas publicaciones durante la década del veinte. El escritor Vicente Rossi, en un libro publicado en 1921, aportó algunos elementos para comprender el derrotero de la obra fallida. ${ }^{12} \mathrm{La}$ convocatoria en Uruguay para la presentación de un proyecto que se inauguró en 1927, y que determinó el emplazamiento del monumento al gaucho en la avenida 18 de Julio -como se muestra en la Figura 2-, una de las principales zonas de tránsito de la ciudad de Montevideo, pareció reavivar las pretensiones por establecer una obra similar al otro lado del Río de la Plata. En efecto, Rossi se aventuraba a recomendar cómo debería ser esa representación en el bronce: “El Monumento al Gaucho no debe ser una época de su evolución, debe ser un

\footnotetext{
${ }^{10}$ CAO, José María, “El monumento al gaucho", en El Hogar, 19 de enero de 1917, pp. 1-2.

${ }^{11}$ El Hogar, 18 de octubre de 1918, p. 1.

12 Vicente Rossi fue un escritor nacido en Uruguay que colaboró durante su juventud con algunas publicaciones de Montevideo, como El Fogón. A fines del siglo XIX se instaló en Argentina, en la provincia de Córdoba, donde produjo sus obras más reconocidas. Ver, ROSSI, Vicente Cosa de negros, Hachette, Buenos Aires, 1958; Teatro nacional rioplatense: contribución a su análisis y a su historia, El Solar-Hachette, Buenos Aires, 1969.
} 
símbolo [...] vayamos, pues, a buscar ese Gaucho, al primero, al que en epopeya aún no cantada, empapó con su sangre el suelo nativo para que jerminase (sic) la semilla de la libertad". ${ }^{13}$

\section{FIGURA 2}

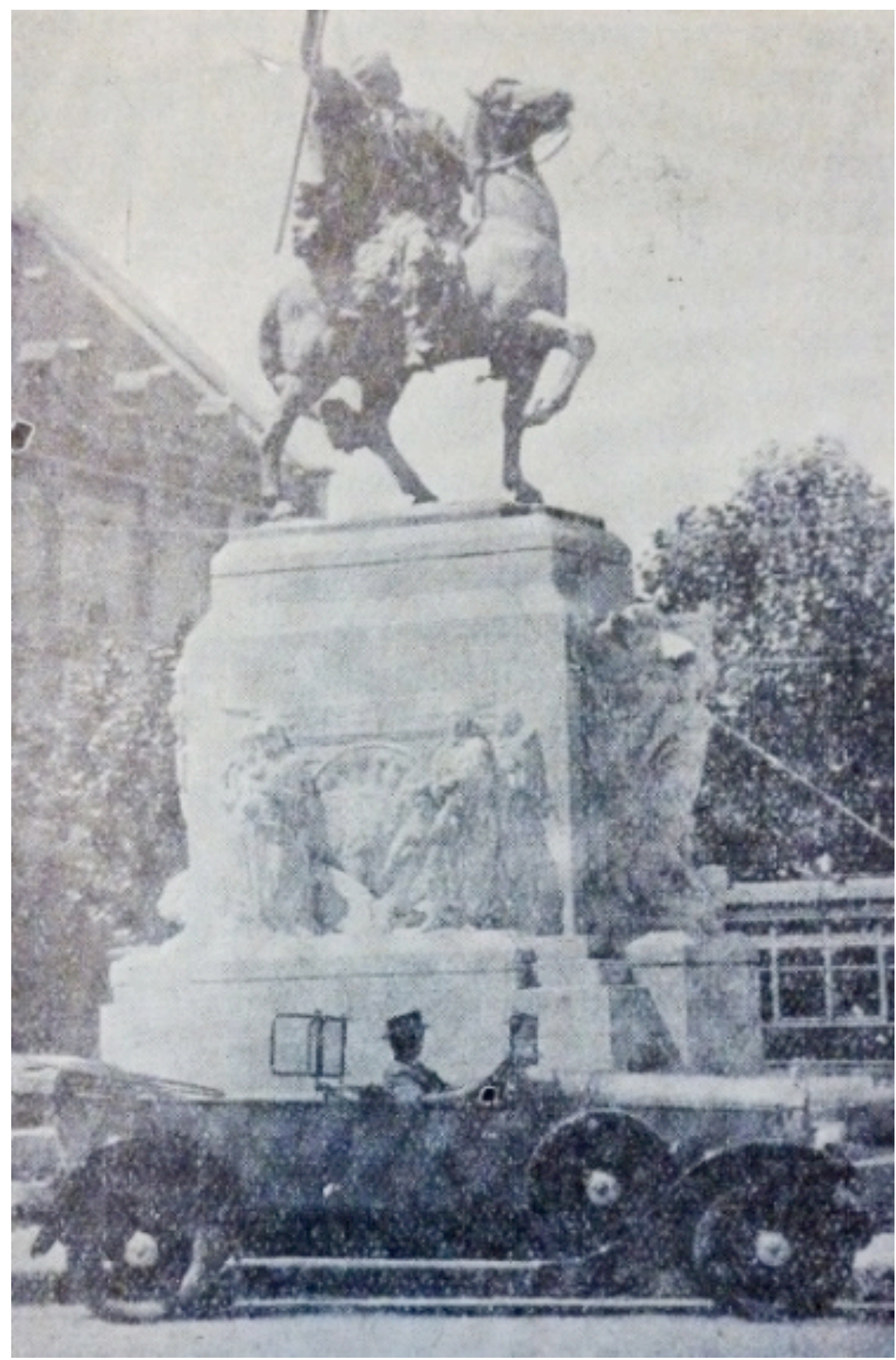

Nativa, revista mensual ilustrada, 31 de agosto de 1942, p. 11.

${ }_{13}$ ROSSI, Vicente El gaucho su orijen y evolución, Edición de la Imprenta Argentina, Río de la Plata, 1921, p. 7. 
El diagnóstico que establecía Rossi sobre la falta de reconocimiento para el gaucho se contraponía a lo visitado anteriormente en las publicaciones de $E l$ Hogar. El autor aquí componía una crítica no a las pretensiones de concretar un proyecto de monumento, sino a las dificultades para cristalizarlo: "Nada, absolutamente nada recuerda en los países del Plata al prócer de los próceres, al invicto Gaucho. Nada, absolutamente nada perpetúa su nombre." El reclamo de Rossi, y la experiencia en Buenos Aires, donde la idea del monumento había quedado en insinuación, teñían de desesperanza su visión sobre el incipiente proyecto uruguayo: "Si esta vez llega a ser un hecho, los manes charrúas harán perpetua guardia de honor al bronce que rememore su glorioso descendiente" ${ }^{14}$ Finalmente, la capital uruguaya se anticipó a los tradicionalistas que soñaban emplazar el homenaje en Buenos Aires.

Hacia finales de la década del veinte y principio de los años treinta se presentaba a Montevideo como una ciudad que entendía la supuesta importancia de conservar las tradiciones. En una descripción de las calles uruguayas, una conocida y difundida publicación bonaerense refería: "Rendimos homenaje a ese monumento de extraño vigor que los uruguayos han levantado al Gaucho, y que nos parece soberbio como una epopeya. Aquí las calles tienen nombres indianos; los anuncios carecen de ese tipo extranjero que predomina en Buenos Aires [...] es una ciudad personal y guardadora de sus tradiciones." 15 La comparación acrecentaba la "deuda" de la capital argentina según lo testimoniaron los impulsores del proyecto en 1936.

El monumento uruguayo le dio continuidad al tópico en Argentina. En julio de 1936, una motivación privada que surgió en la ciudad balnearia de Mar del Plata avanzó hasta plasmar el proyecto en un comunicado entregado al Concejo Deliberante del lugar. La iniciativa la había concebido el vecino Tomás Vignolo, miembro de una familia acaudalada de la zona, poseedora de establecimientos rurales. Él presidió la comisión pro-monumento que realizó diversas actividades para fomentar la concreción del homenaje y la difusión de actividades tradicionalistas. ${ }^{16}$ Llamativamente, la presentación del esbozo del monumento fue cuestionada por la revista Nativa. Esa publicación mensual fue fundada a fines de 1923 con una tirada de 6 mil ejemplares para su primer número. ${ }^{17}$ Era dirigida por un referente del folklore y el tradicionalismo argentino, Julio Díaz Usandivaras. El director tomaba a su cargo las editoriales

\footnotetext{
${ }^{14}$ ROSSI, Vicente El gaucho...cit., p. 44.

${ }^{15}$ MARTÍNEZ, Lola Pita "Cartas de viaje", en Caras y Caretas, 30 de marzo de 1929, p. 37.

${ }_{16}$ Para mencionar un ejemplo, la Comisión pro-monumento al gaucho de la ciudad de Mar del Plata patrocinaba, en esa ciudad, las emisiones radiales de Anacleto Peñaloza "gaucho de veras". Un programa donde se atacaban a quienes "falseaban la tradición". Ver, Caras y Caretas, 7 de enero de 1939.

${ }^{17}$ La cifra se reseñaba en un número dedicado casi íntegramente a la trayectoria de la revista con motivo de su vigésimo aniversario, Nativa. Revista mensual ilustrada, 31 de diciembre de 1943.
} 
que se publicaban en las primeras páginas y promovía la difusión de obras literarias y folklóricas, no solo desde la revista sino también a través de compilaciones diversas. ${ }^{18}$ Nativa experimentó un rápido crecimiento durante sus primeros años: al celebrar su tercer aniversario, se destacaba la participación de más de trescientos agentes y corresponsales en todo el país y el número de dos mil suscriptores fijos. ${ }^{19}$ En la revista, las alusiones al gaucho y la tradición resultaban un denominador común, de hecho, constituían su leitmotiv. No obstante, desestimaron el proyecto no por pretender concretar un monumento con el cual la línea editorial de la publicación comulgaba, sino por partir de voluntades individuales e intereses privados. En efecto, la obra se iba a financiar a partir de la venta de un terreno que ofrecía Vignolo. Nativa prestaba su "más sonoroso aplauso" a la "iniciativa patriótica" pero reconocía un supuesto peligro: "El monumento a ese personaje trascendental de nuestra historia debe tener carácter nacional. Toda iniciativa o hecho aislado a este respecto podría obstaculizar la realización del monumento imaginado por nosotros [...] un homenaje rendido al gaucho por todo el pueblo de la República." 20

El conflicto parecía plantearse desde dos perspectivas, una en clave de reconocimiento territorial que se ponía de relieve al mencionar la "deuda" que todo el país tenía con el gaucho. Es decir, la supuesta reivindicación que se vislumbraba en Mar del Plata debía, según los redactores de Nativa, alcanzar niveles nacionales para resultar efectiva. Por otro lado, esa crítica se complementaba con la actitud aislada e individual del proyecto. En otras palabras, lo que la editorial reclamaba era una amplitud de consenso para concretar ese homenaje que veían inviable por la inacción del gobierno nacional. En efecto, en febrero de 1937 se realizó una fiesta en una de las estancias de Vignolo para celebrar la colocación de la piedra fundamental del monumento que, como muestra la Figura 3, ya tenía su maqueta. Sin embargo, el proyecto debería esperar muchos años para verse cristalizado. ${ }^{21}$

18 Ver, entre otras, DÍAZ USANDIVARAS, Julio (ed.) Folklore y tradición: antología argentina, Editorial Raigal, Buenos Aires, 1953; 5 siglos de literatura argentina, Ediciones Corregidor, Buenos Aires, 1993.

${ }^{19}$ Ver, Nativa. Revista mensual ilustrada, 31 de diciembre de 1926.

${ }^{20}$ DÍAZ USANDIVARAS, Julio "Sobre un monumento al gaucho", en Nativa, revista mensual ilustrada, 31 de agosto de 1936, pp. 25-26.

${ }^{21}$ DÍAZ USANDIVARAS, Julio "Un criollo de verdad es el señor Tomás Vignolo", en Nativa, revista mensual ilustrada, 31 de julio de 1937, pp. 4-5. Diez años después el senador Eduardo Molina realizaba un repaso por los proyectos fallidos de monumento al gaucho y al referirse a la iniciativa en Mar del Plata aseguraba: "quedó en la nada", MOLINA, Eduardo "Fundamentos verbales del proyecto de ley sobre erección de un monumento al gaucho", 16 de mayo de 1947, citado en TIMPONE, Francisco (comp.) Día de la Tradición...cit., p. 61. Recién a comienzos de la década del sesenta, la ciudad balnearia concretaría el homenaje en la intersección de la avenida Champagnat y Juan B. Justo. 


\section{FIGURA 3}

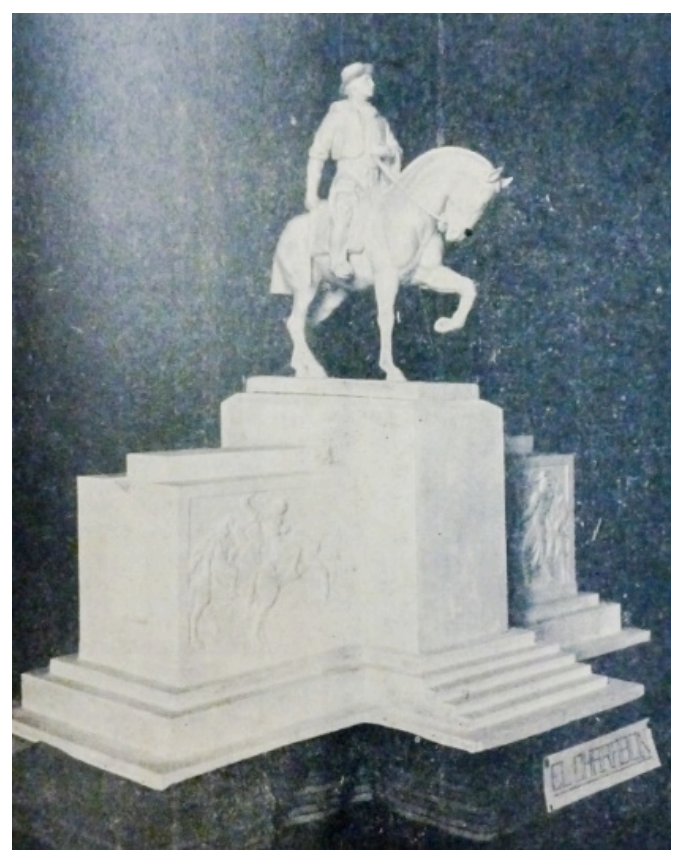

Nativa, revista mensual ilustrada, 31 de julio de 1937, p. 5.

Durante la década del cuarenta, con las celebraciones anuales del Día de la Tradición creciendo en organización y participación, la temática del monumento al gaucho resurgió con tentativas de proyectos en dos momentos particulares. En 1943, por iniciativa de la Federación Gaucha Bonaerense, institución concebida por la Agrupación Bases, se conformó una comisión pro monumento que incluía, entre otros, al citado Francisco Timpone, reconocido como "el Padre del Día de la Tradición" por ser el mentor de la efeméride y su principal impulsor. ${ }^{22}$ De acuerdo a la correspondencia privada entre los integrantes de la comisión, el proyecto parecía contar con el respaldo del Gobierno provincial dirigido por los conservadores. El gobernador Rodolfo Moreno habría supervisado la lista de los integrantes y los habría recibido los últimos días del mes de enero para avanzar en el proyecto. ${ }^{23}$

Su sucesor en la gobernación fue Edgardo Míguez, que poseía un vínculo amistoso con el secretario general de Bases y se había preocupado por las cuestiones gauchescas en distintas oportunidades. En una epístola personal enviada a Francisco Timpone, Míguez reconocía haber contribuido con sincero entusiasmo al proyecto de sancionar el Día de la Tradición por su carácter de

\footnotetext{
${ }^{22}$ "Figuras Básicas", Libro de actas, Archivo de Agrupación Bases. Museo de Almafuerte, La Plata.

${ }^{23}$ Carta de Francisco Timpone a Pedro de María, Archivo de Agrupación Bases, 20 de enero de 1943.
} 
“platense y argentino sin doblez". Además, le expresaba su disponibilidad para nuevas tentativas: "cuente conmigo para cualquier patriada tradicionalista que he de hacerlo quedar bien ante toda emergencia." 24

Esa filiación con la tradición nacional lo había llevado a comprometerse con la tarea del monumento al gaucho. En una salutación con motivo de la Fiesta de la Tradición, el ex gobernador se lamentaba años después por el malogrado proyecto, y atribuía el fallido a "la revolución imperante", en referencia al golpe de Estado de junio de 1943 que decretó la intervención de la provincia y el fin de su mandato. ${ }^{25}$ La planificación para instituir el monumento en La Plata, que avanzaba al calor del respaldo conservador, se truncó por los cambios políticos.

La anulación del proyecto pareció responder más a los vaivenes coyunturales que a la desestimación por parte de los militares que accedieron al poder a partir de ese golpe de Estado. Como antesala de lo que se plasmó durante el peronismo, los sucesivos gobiernos -fundamentalmente el de Pedro Ramírez- revisitaron la figura del gaucho como símbolo de la argentinidad e intervinieron en las voces detractoras que cuestionaban esa construcción. ${ }^{26}$

En 1947, los representantes provinciales del partido radical reflotaron el proyecto y la propuesta fue debatida en el parlamento bonaerense. Allí se puso de relieve la disputa entre radicales y peronistas por las apropiaciones partidarias de la figura del gaucho. El tutelaje del peronismo sobre las cuestiones de la tradición sería cuestionado por los discursos de los funcionarios opositores. Más allá de la eficacia de las propuestas, esos intercambios evidenciaron que el gaucho continuaba significando un polo de atención particular para los políticos de la provincia.

\section{Entre peronistas y radicales. La apropiación de la figura del gaucho desde los partidos políticos}

La puja por identificar al gaucho con diferentes partidos políticos, planteada en la legislatura bonaerense, no constituyó una novedad. A partir de mediados de la década del treinta, la mayoría de las identidades partidarias estaban en proceso de construcción o reformulación, esa búsqueda conllevaba una relectura sobre el pasado en pos de incorporar elementos de una supuesta

24 Carta de Eduardo Míguez a Francisco Timpone, Archivo de Agrupación Bases, 9 de noviembre de 1945.

25 Carta de Edgardo Míguez a Francisco Timporne, Archivo de Agrupación Bases, 9 de noviembre de 1945.

26 En otro trabajo hemos presentado un ejemplo de intervención gubernamental, ver, CASAS, Matías “Las Bases de la tradición. El rol de la Agrupación Bases en la consolidación del gaucho como símbolo nacional. Provincia de Buenos Aires, 1939", en Cuadernos del Sur, Universidad Nacional del Sur, núm. 39, 2012, pp. 55-72. 
"tradición nacional". ${ }^{27}$ El Partido Socialista fue una de las corrientes políticas que se interesó por la figura del gaucho y por la semántica de sus representaciones en ese contexto. Como bien demuestra Marcela Gené, en su estudio sobre las imágenes de los trabajadores, los socialistas utilizaron la iconografía gauchesca en sus bocetos de campaña. En general, el gaucho aparecía representando al "pueblo" que se figuraba abatido por la corrupción y el fraude, dos ejes críticos permanentes durante los últimos años de la década. ${ }^{28}$

La representación del gaucho y la tradición que sostuvieron los sectores socialistas no solo se advertía en los panfletos de campaña. En 1930 se había fundado la Revista Socialista bajo la dirección del economista Rómulo Bogliolo. La ampliación temática que experimentó la publicación durante sus primeros años incluyó diversas críticas a manifestaciones artísticas, como la publicada por el dramaturgo socialista Román Gómez Masía. En una de sus críticas cuestionó la representación del campo y sus habitantes que se escenificaban en la obra de Alberto Vaccarezza, Lo que le pasó a Reynoso. En el texto, Gómez Masía argumentaba: "El campo no es, como dice Vaccarezza, un amable escenario para guitarreos y malambos para chascarrillos y chiripas [...] El campo es un inmenso taller donde los hombres trabajan, sufren [...] en la lucha sorda contra el hombre de las ciudades que se apropia del fruto de aquel trabajo." 29 Esa descripción, vislumbraba la perspectiva desde la que los socialistas se aproximaron a la figura del gaucho. La representación que circuló en el ámbito del partido, fundado en los albores del siglo XIX, fue la del gaucho explotado que, pese a la hostilidad de las condiciones laborales, sociales y políticas, habría conservado y legado un espíritu indómito. El gaucho, para los socialistas, se transformaba en canal de críticas contra las injusticias sociales y en referencia para la situación laboral de los habitantes rurales. ${ }^{30}$

${ }^{27}$ CATTARUZZA, Alejandro "Descifrando pasados: debates y representaciones de la historia nacional", en CATTARUZZA, Alejandro (dir.) Nueva Historia Argentina, tomo VII, Los años treinta, Sudamericana, Buenos Aires, 2002, p. 434.

28 GENÉ, Marcela Un mundo feliz. Imágenes de los trabajadores en el primer peronismo, 1946-1955, Fondo de Cultura Económica, Buenos Aires, 2008, pp. 111-112.

${ }^{29}$ GÓMEZ MASÍA, Román "El campo argentino desde Vaccarezza a Cerretani", en Revista Socialista, julio de 1936, pp. 67-68.

${ }^{30}$ En las mencionadas palabras del diputado socialista Carlos Sánchez Viamonte durante el debate legislativo del proyecto para instituir el Día de la Tradición, se retomaba la inherente rebeldía de los criollos del campo que, como Martín Fierro: "parece representar de modo intuitivo el afán de justicia distributiva que anima a la humanidad", ver, SÁNCHEZ VIAMONTE, Carlos "Sanción del proyecto de ley que instituye el 10 de noviembre como Día de la Tradición", 9 de agosto de 1939, citado en TIMPONE, Francisco (comp.) Día de la Tradición...cit., pp. 21-24. La utilización de la figura del gaucho desde la izquierda argentina no se circunscribió al partido socialista. En 1963, el comunista Eduardo Astesano publicó Martín Fierro y la Justicia Social. Primer manifiesto revolucionario del movimiento obrero argentino [Ediciones Relevo, Buenos Aires], realizando hincapié en la "epopeya" del sector social más bajo que representaría el gaucho de Hernández y poniendo de relieve su supuesto carácter 
Los elementos resaltados por los políticos conservadores en relación a la figura del gaucho no estuvieron supeditados a la situación socioeconómica contemporánea de los campesinos de la pampa. Desde la recuperación de su figura que se plasmó en la ley de 1939 -con los indicios previos que habían manifestado las políticas del gobernador Manuel Fresco en la provincia de Buenos Aires- los conservadores apelaron al carácter romántico del "pasado gauchesco". En efecto, la representación construida desde el conservadorismo no se correspondía con la pretensión de delinear una serie de cuestionamientos a los funcionarios de turno, entendiendo que eran ellos quienes gobernaban la provincia en los últimos años de la década del treinta cuando el tópico comenzaba a captar la atención de otras identificaciones políticas. Al mismo tiempo, los conservadores parecían ostentar una suerte de potestad sobre la figura del gaucho sustentada en haber sido el sector político que radicó el proyecto sobre el Día de la Tradición y desarrolló sus primeros festejos. Así lo testimoniaba el conservador Eduardo Míguez, en la citada carta a Francisco Timpone, cuando se lamentaba por la imposibilidad de concretar el monumento al gaucho "que solo el conservadorismo hubiera sido capaz de llevar a cabo sin riesgo de fracaso." 31

La supuesta tutela que los conservadores pretendieron ejercer sobre la figura del gaucho fue discutida por la irrupción de la fuerza política que trastocó la arena partidaria a mediados de los años cuarenta: el peronismo. ${ }^{32} \mathrm{El}$ gaucho transitó, a partir de la asunción de Juan Domingo Perón como presidente de la Argentina, su propio proceso de "peronización". Ese recorrido se entendía desde un proyecto más amplio del peronismo que consistía en monopolizar el espacio simbólico. Como plantea Mariano Plotkin, la peronización de la sociedad estaba ligada a la idea de "unidad espiritual" que pretendía llevarse a cabo a partir de la construcción de un aparato simbólico y su institucionalización. ${ }^{33}$

Varios elementos permiten identificar el paulatino camino de articulación que se buscó tejer entre la "identidad peronista" y la figura del

revolucionario. En la misma coyuntura, la agrupación anarquista "Libertaria" de la ciudad de Mar del Plata publicó un comunicado titulado "Carta gaucha" donde proclamaba los principios de su ideología en estilo gauchesco. Ver, WOOLLANDS, Luis Carta gaucha y la descendencia del Viejo Vizcacha, Impresiones el Sol, Buenos Aires, 1960.

31 Carta de Edgardo Míguez a Francisco Timpone, Archivo de Agrupación Bases, 9 de noviembre de 1945.

32 Sobre el desarrollo del peronismo y su dinámica en los diversos ámbitos de la vida política, social y cultural, ver, entre otros, FIORUCCI, Flavia Intelectuales y peronismo: 1945-1955, Biblos, Buenos Aires, 2011; COSSE, Isabella Estigmas de nacimiento. Peronismo y orden familiar, 1946-1955, Fondo de Cultura Económica, Buenos Aires, 2006; ACHA, Omar, Los muchachos peronistas, los orígenes olvidados de la juventud peronista, Planeta, Buenos Aires, 2011.

${ }_{3}^{3}$ PLOTKIN, Mariano Mañana es San Perón: propaganda, rituales políticos y educación en el régimen peronista (1946-1955), Ariel Historia Argentina, Buenos Aires, 1994. 
gaucho. El peronismo no resignó el carácter telúrico del gaucho para reconstruir su representación y estrecharlo a sus intereses políticos. Uno de los factores que promulgaron la ligazón identitaria entre gauchos y peronistas fueron las medidas gubernamentales desarrolladas por Perón. La transformación de una "Argentina asimiladora de cultura" a una "creadora" fue una de las premisas discursivas más recurrentes del líder. Para esa pretendida transformación, Perón ponía especial acento en las expresiones folklóricas: "deben ser estudiadas; el sentir del pueblo interpretado por danzas, música y canciones, debe cuidarse como expresión de íntima y popular cultura." 34 Ese contexto resultó propicio para recuperar la tónica tradicionalista y revalorizar el criollismo como expresión cultural autóctona. En una emisión de Radio del Estado, de junio de 1947, se esbozaban argumentos que permitían identificar los propósitos de la recuperación de las tradiciones: "En la medida en que se intensifique esta readaptación a las vivencias tradicionalistas, se obtendrá, como feliz resultado la neutralización de corrientes foráneas perniciosas y modas extranjeras de importación, para salvar las fuentes prístinas de la inspiración vernácula y los valores perennes de nuestra propia personalidad."35

La representación que se puso en juego -y que el mismo Perón se encargó de difundir- no solo se vinculaba a lo vernáculo y a los componentes idealizados de la pampa, sino que identificaba al gaucho con el colectivo de "trabajador". Esa representación trazaba lazos cronológicos con los peones rurales del período y lo colocaba como uno de los "redimidos" por la "justicia social" que tanto se pregonó desde el Gobierno. En esa línea, el presidente de la Nación, en ocasión de fundamentar el proyecto de ley para emplazar un monumento a la figura del "descamisado", lo identificaba al gaucho en el proceso de organización nacional y tendía la continuidad con el pasado: "Ese descamisado que fue carne de cañón en la Independencia, que fue el gaucho de las cuchillas y las chuzas en la organización nacional y el mismo que después levantó los edificios e hizo grande la patria". ${ }^{36}$ Así, en la construcción de los "descamisados", no solo se representaban los obreros industriales, sino que se incorporaba a los trabajadores rurales a partir de la simbólica figura del gaucho. ${ }^{37}$

\footnotetext{
${ }^{34}$ Ver, por ejemplo, PERÓN, Juan "La revolución argentina en el panorama de la política mundial", citado en TIMPONE Francisco (comp.) Día de la Tradición...cit., p. 92.

${ }_{35}$ Radio del Estado, 12 de junio de 1947. La alocución fue pronunciada en el programa de la Unión Argentina de Trabajadores Intelectuales, ver transcripción en, TIMPONE Francisco (comp.) Día de la Tradición...cit., p. 93.

36 PERÓN, Juan y BORLENGHI, Ángel Fundamentos del proyecto de ley del monumento al descamisado, tomo V, CDDS, Buenos Aires, 1946, p.391.

37 Otra identificación entre la figura del gaucho y el descamisado se presentó en un libro publicado en 1955. El primer capítulo de la obra se denominaba "Martín Fierro, primer descamisado". En pos de oponer al protagonista al "régimen oligárquico burgués" se pretendía legitimar la relación en los versos del poema de José Hernández: "yo no tenía ni camisa, ni cosa
} 
Pese a los marcados intentos por consolidar un consenso en orden a la representación del "gaucho peronista", en los últimos años de la década del cuarenta aparecieron intersticios por los cuales se filtraron otras voces que reconstruyeron representaciones disímiles, en ocasiones contradictorias con la propuesta del Gobierno nacional. Las conocidas caricaturas antiperonistas de Tristán, publicadas en el semanario socialista La Vanguardia representaban al pueblo argentino en la figura del gaucho. Como muestra Marcela Gené, esa representación partía del supuesto descontento del "pueblo" con Perón. En una de las imágenes que la historiadora presenta se reconoce al gaucho, con alegría en su rostro, dejando atrás el período de "dictadura" y saltando hacia la "normalidad" en una interpretación particular de las búsquedas políticas. ${ }^{38}$

Otra objeción a la utilización peronista de la figura del gaucho se encuentra en un libro de cuentos gauchescos publicado en 1949. El autor era Osvaldo Vargas Molteni, nacido en la localidad de Tres Arroyos donde estaban ambientados la mayoría de sus cuentos. Su trayectoria remitía a una prolífera producción de relatos cortos y breves novelas gauchescas que comenzaron a aparecer a finales de la década del veinte en la revista Fray Mocho. Con el título Palenque Pampa publicó la recopilación de su colección. En el prólogo de ese libro se advertía sobre los usos a los que era sometida la figura del gaucho: "Entre nosotros el personaje ha sido explotado y zarandeado en una casi idéntica y falsa concepción típica." Sin hacer referencia explícita a Perón, las palabras preliminares concluían: "en esta época de tendencias deformadoras se pretende hacer de todo hecho histórico, de toda realidad objetiva, un símbolo para la militancia." ${ }^{39} \mathrm{El}$ texto intentaba deconstruir la relación entre el gaucho y el peronismo desligándolo de toda tipificación y cuestionando su utilización partidaria.

Otra de las reacciones ante el proceso de "peronización" del gaucho se valió, también, de una tipificación pero construida desde una perspectiva diferente. En los debates legislativos del proyecto para construir un monumento al gaucho en 1947, los diputadores y senadores radicales de la provincia de Buenos Aires pretendieron discutir la supuesta inequívoca vinculación entre el gaucho y Perón. El argumento principal para aproximar su figura a las filas del partido consistía en ser los impulsores del proyecto. El senador Eduardo Molina llevó el debate a la legislatura bonaerense, y varios de los diputados que tomaron la palabra se encargaron de confirmar el carácter radical de la iniciativa. El proyecto no surgió de una persona ajena a las reivindicaciones gauchas. Por el contrario, Eduardo Molina era un acaudalado estanciero de Tres Arroyos, en la zona sur de la provincia, que se desempeñó como vicepresidente

que se parezca; mis trapos solo pa yesca, me podían servir al fin." Ver, BERTOTTO, José Mi amigo Martín Fierro, Librería Ruiz Editorial, Rosario, 1955.

38 GENÉ, Marcela Un mundo...cit., pp. 112-113.

39 VARGAS MOLTENI, Osvaldo Palenque Pampa, Editorial Bell, Buenos Aires, 1949, pp. 9-17. 
de la agrupación tradicionalista El Ceibo. En su estancia asumía el rol de orador en los fogones de sus peones recuperando anécdotas de hechos "heroicos" que tenían como protagonistas a los gauchos. Además, solía organizar yerras y domas entre los trabajadores, quienes -por decisión del patrón- se vestían a la vieja usanza con chiripá y botas de potro. ${ }^{40}$ Molina consideraba que su accionar contribuía a conservar las tradiciones auténticas que se veían "tergiversadas" por la presencia de inmigrantes en los campos: “Estos gringos pícaros nos han traído un montón de cosas buenas, pero revuelto con eso, otro montón de mañas y perversiones que no tenían los nativos antes que los gringos se contaran por cientos de miles". ${ }^{41}$ Con su indumentaria -como se advierte en la Figura 4- y sus prácticas camperas sostenía la convicción de contrarrestar ese proceso. En la coyuntura del peronismo, Molina en tanto "gaucho" y radical, se afanó en reaccionar ante lo que entendía como otra tergiversación: la identificación de su figura con el movimiento político gobernante.

FIGURA 4

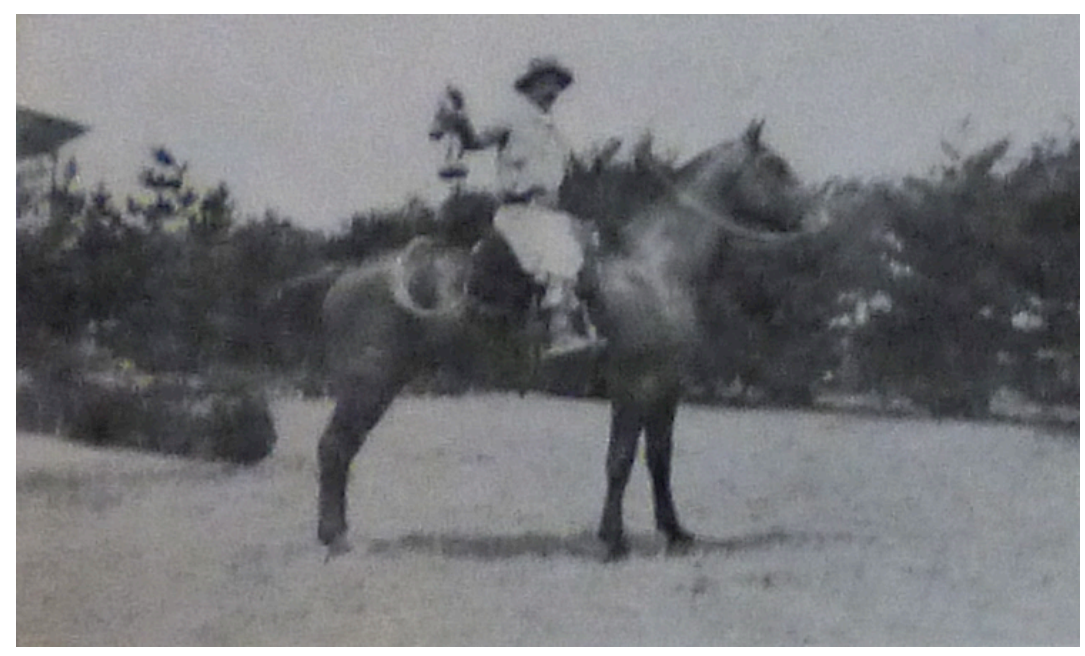

Nativa revista mensual ilustrada, 31 de enero de 1929.

El debate parlamentario -tanto en la Cámara de Senadores como en la Cámara de Diputados- se prolongó en diferentes sesiones ordinarias que se produjeron entre mayo de 1947 y agosto de 1948. Detenerse en los componentes particulares de cada alocución atentaría contra la extensión de este trabajo. Las contradicciones, particularmente en torno a la financiación del proyecto determinarían un nuevo fracaso para los reivindicadores del gaucho. En general, los funcionarios que intervinieron en las discusiones no se

\footnotetext{
40 No solo en la estancia "San Eduardo" organizaba eventos públicos, también en su casa presentaba funciones de danzas y cantos nativos, práctica que era celebrada en la revista Nativa en tanto cultora de "sano nacionalismo". Ver, Nativa revista mensual ilustrada, 30 de abril de 1929. ${ }^{41}$ MOLINA, Eduardo, "Siluetas nacionalistas", en Nativa revista mensual ilustrada, 31 de enero de 1929.
} 
manifestaron reticentes a evocar lo gauchesco desde el bronce como un homenaje legítimo al "arquetipo de la nacionalidad". Empero, las tensiones se conjugaron más a partir de las diferencias políticas preexistentes que en referencia al homenaje al gaucho.

En la Cámara de Senadores las dos intervenciones que impulsaron el proyecto de ley se pronunciaron desde la bancada radical. En primer lugar, Eduardo Molina - a quien Oscar Aelo lo identifica en uno de sus trabajos como componente del radicalismo intransigente- fundamentó la presentación de la iniciativa. ${ }^{42}$ En su discurso realizó un extenso recorrido sobre el obrar del gaucho en los episodios destacados por la historiografía liberal, matizado con citas de reconocidos tradicionalistas que complementaban su enfoque laudatorio sobre los gauchos de la campaña. Su discurso no dejó huellas explícitas sobre la propiedad radical del homenaje. No obstante, entre las citas señaladas la única que remitía al escenario político era la del diputado Emilio Ferreyra que se había desempeñado como legislador bonaerense -por el mismo partido- entre 1936 y 1940. Ferreyra había intervenido en los debates por la institución del Día de la Tradición en 1939. La decisión de citar de modo textual sus palabras en esas sesiones pretendía marcar una ligazón y una continuidad partidaria en la "recuperación" del gaucho. A esas voces, se le sumó Vicente Biscayart quien celebró la procedencia del proyecto y alentó a la votación favorable. ${ }^{43}$

Esa identificación trazada desde la Cámara de Senadores -en orden a las nulas intervenciones de otros sectores políticos- se corrompió con la participación de los diputados que discutieron el proyecto. Además de las álgidas contradicciones sobre el financiamiento de la obra, en los discursos de dos diputados peronistas se advertía un nivel de cuestionamiento que iba más allá de la materialidad del monumento. El legislador Mariano Arrieta -puntano que había ejercido como funcionario en el Consejo General de Educación de la provincia de Buenos Aires- relativizó los discursos sobre el gaucho: "Hablar del gaucho argentino en momentos en que soplan por el territorio de nuestra patria vientos de reivindicación de todo lo que es auténticamente nuestro es casi una redundancia." 44 De ese modo, parecía delimitar el territorio de las reivindicaciones al gaucho aludiendo que la restitución de derechos no se

\footnotetext{
42 AELO, Oscar "¿Continuidad o ruptura? La clase política bonaerense en los orígenes del peronismo", en Anuario IEHS, núm. 17, 2002, p. 365.

${ }^{43}$ MOLINA, Eduardo, Fundamentos verbales del proyecto de ley sobre erección de un monumento al gaucho", 16 de mayo de 1947, citado en TIMPONE, Francisco (comp.) Día de la Tradición...cit., pp. 59-65.

${ }^{44}$ ARRIETA, Mariano "Aprobación en general y particular con modificaciones del proyecto de ley en revisión referente a la erección de un monumento al gaucho en la ciudad de La Plata", 4 de agosto de 1948, citado en TIMPONE Francisco (comp.) Día de la Tradición...cit., p. 70.
} 
circunscribía al campo de lo simbólico sino a los "vientos" justicialistas que soplaban desde el Gobierno.

Esa perspectiva se plasmó de modo más directo en la intervención de Justo Mouzo, diputado de pasado en la Unión Cívica Radical que, en una práctica recurrente, había abrazado las filas del peronismo. Para Mouzo el gaucho no había muerto como lo habían aseverado otros diputados. Por el contrario, los reconocía -con costumbres modificadas- en las estancias atendiendo las faenas camperas. Ese desplazamiento resultaba fundamental para concluir su interpretación: “Ese gaucho ya tiene su monumento en el corazón de los ciudadanos argentinos y en la voluntad del gobierno que rige actualmente en la República Argentina, porque el mayor monumento que se puede erigir al gaucho está en la legislación que lo protege contra las violencias y los abusos del capitalismo." 45 La distinción realizada por Mouzo se emparenta a la concepción de monumento histórico propuesta por Françoise Choay en tanto remarca que su concreción está sujeta a una distancia temporal que genera una lectura sobre el pasado diferenciándolo del tiempo desde el cual se proyecta. ${ }^{46}$ Allí estaba entonces el gaucho de los diputados peronistas, que ya se entendía homenajeado mediante las políticas laborales implementadas por el líder de ese movimiento. Empero, las "aclaraciones" procedentes de esa bancada no significaron la oposición al proyecto. La reivindicación criolla del peronismo hubiera sufrido una llamativa contradicción si los legisladores desestimaban un homenaje al símbolo de la tradición.

Ante las reinterpretaciones de los diputados citados, el radical Luis Vera confirmó la preeminencia de un gaucho radical en un discurso pronunciado durante la misma sesión. El funcionario se explayó en la supuesta filiación entre el gaucho y el partido: "ninguno de los miembros de la bancada radical trata de retacear el homenaje al gaucho [...] el proyecto original es de un Senador de nuestro sector, vale decir, que tiene que estar apoyado por el calor y la adhesión partidaria de todos los hombres que integran esta bancada". En esa suerte de aclaración introductoria, el diputado despejaba cualquier posible cuestionamiento y pretendía consolidar la adhesión total de su bloque al proyecto. Para argumentar esa posición proyectaba esa identificación a los comienzos de la Unión Cívica Radical y expresaba sobre el gaucho: "que ha nutrido de forma tan magnífica las filas del ejército en la hora de la liberación de la patria y de la organización nacional, que se enroló voluntariamente en los comienzos de la Unión Cívica Radical en esta provincia de Buenos Aires." 47 En las palabras de Vera se reconfiguraba al gaucho. Es decir, el mensaje del

\footnotetext{
${ }_{45}$ MOUZO, Justo "De la sesión del 7 de octubre de 1948", citado en TIMPONE, Francisco (comp.) Día de la Tradición...cit., p. 86.

${ }^{46}$ CHOAY, Françoise Alegoría del patrimonio, Gustavo Gili, Barcelona, 2007.

${ }^{47}$ VERA, Luis "De la sesión del 7 de octubre de 1948”, citado en TIMPONE, Francisco (comp.)

Día de la Tradición...cit., pp. 84-85.
} 
diputado remarcaba una filiación primaria, anterior a la construcción peronista, que se visibilizaba para reclamar una suerte de "potestad" sobre su figura. Luis Vera no solo les confirmaba a los diputados peronistas que el gaucho había elegido libremente adherirse al partido de Leandro Alem sino que, al mismo tiempo, remarcaba la historicidad de ese sector político. Desde esa perspectiva se justificaba el "calor" de los radicales que acompañaban la propuesta.

La pertinencia del monumento parecía fuera de discusión para todos los legisladores. No obstante los desencuentros en torno a la financiación complejizaron el tratamiento. El homenaje nuevamente quedaría en discurso de intenciones. Sin embargo, las tensiones políticas alrededor del gaucho se prolongaron. Los discursos allí pronunciados visibilizaron una disputa bipartidaria. Mientras que los senadores y diputados radicales pusieron el acento en la concepción de la propuesta y la pretendida participación política del gaucho bajo sus banderas, los peronistas se concentraron en las transformaciones coyunturales impulsadas desde el Gobierno.

Como intentaba confirmar Mouzo, la identificación entre el peronismo y el gaucho no se construyó solo a partir de una faceta discursiva, sino que pretendió sustentarse desde medidas concretas de Juan Domingo Perón. La primera de las políticas destacadas se había concretado desde sus funciones como secretario de Trabajo y Previsión en 1944. En octubre de ese año, un decreto del Poder Ejecutivo, aprobó el estatuto del peón de campo por él impulsado. Allí se reconocían una serie de derechos laborales para los trabajadores rurales que incluía el descanso dominical y las vacaciones pagas entre otras conquistas. Esa medida, que luego devendría en ley durante la presidencia de Perón, sería motivo de agradecimiento y demostraciones posteriores por parte de los tradicionalistas.

Durante su mandato, el impulso del criollismo se cristalizó -entre otras medidas- con el decreto presidencial $\mathrm{N}^{\circ} 3.454$, sancionado en 1948, que nacionalizó el Día de la Tradición. En la tarde del 9 de noviembre de ese año, el presidente decidió oficializar la expansión del festejo a todo el territorio argentino. Las expectativas de los tradicionalistas pioneros en el proyecto de 1939 se veían cristalizadas en un contexto político bien diferente. De hecho, ni las comuniones ideológicas con Manuel Fresco ni el tutelaje conservador, que había sido resaltado por Edgardo Míguez, lograron lo que el peronismo se adjudicaba a partir del decreto. Esa sanción significaba la culminación de un paulatino proceso de diversificación de las Fiestas de la Tradición -un signo evidente de esa expansión había sido la nacionalización de las conmemoraciones escolares de esa efeméride en 1943. Con el respaldo del Gobierno nacional, se promovía, a partir del decreto, la organización de festejos en distintos puntos del país. 
Los fundamentos de la sanción confirmaban que la "solemnidad de la fiesta" ameritaba su nacionalización. No se presentaban pormenorizados argumentos de la extensión del festejo sino que directamente se reconocía a la obra de José Hernández como poema épico nacional. En el texto se daba por sentado que lo narrado en el Martín Fierro se condecía con las experiencias de los gauchos de todo el país. Además, se definía al autor como: "el poeta consagrado por la devoción publica como la máxima expresión de la argentinidad". Desde esa perspectiva, la efeméride fomentaba el cultivo de "las más puras esencias del alma argentina" que se encontrarían en el poema. ${ }^{48}$ Por último, se trazaba una analogía con el "Día de la Raza" celebrado cada 12 de octubre en los países hispanoamericanos. El Poder Ejecutivo consideraba que así como se había instituido esa fecha para celebrar la confraternidad americana, el Día de la Tradición pasaría a integrar al pueblo argentino en la conmemoración del pasado colectivo. ${ }^{49}$ Por último, el decreto disponía: clases alusivas en todas las escuelas del país, audiciones en las radios oficiales, y actos a cargo de los organismos culturales del Estado. ${ }^{50}$ El breve texto que fundamentaba la medida permitía inferir una cierta apertura en las modalidades evocativas que fomentaban, ahora, la integración de diversas regiones.

Los mecanismos de integración y asimilación de la Fiesta de la Tradición en las provincias a partir de 1948 requerirían una investigación particular. Empero, algunos indicios se pueden considerar en orden a los festejos que se concretaron gracias al decreto de Perón. La revista Nativa celebró la medida y dio cuenta de dos experiencias festivas. La Peña Nativa de Resistencia, capital de la provincia de Chaco, en el norte del país, organizó un programa de festejos que involucró conferencias, bailes, homenajes y reglamentos. La reseña sobre las actividades propuestas resalta las similitudes con los organigramas festivos de los tradicionalistas bonaerenses. En la estructura de la fiesta chaqueña se anunciaba: una alocución sobre la personalidad del gaucho; un festival infantil titulado "Evocación del gaucho a través del tiempo"; una disertación sobre la escritura del Martín Fierro y un concurso de composiciones para alumnos de la escuela secundaria; un homenaje al General San Martín a partir de la entronización de un busto; y el baile del pericón nacional para cerrar los festejos. Como condición para participar en esa culminación se explicitaba: "presentarse con indumentarias gauchescas." ${ }^{51}$ El mismo cierre se le dio a la conmemoración en la escuela de maestros "José M. Estrada" de la ciudad de Corrientes, en la provincia homónima del noreste argentino. El cuadro se completó allí con los honores a la bandera nacional. La fiesta se leía desde la

\footnotetext{
48 Noticias Gráficas, 10 de noviembre de 1948, p. 8.

${ }^{49}$ El Mundo, 10 de noviembre de 1948, p. 16.

50 Noticias Gráficas, 10 de noviembre de 1948, p. 8.

${ }^{51}$ Nativa revista mensual ilustrada, 30 de noviembre de 1948, p. 5.
} 
revista como "un voto de eternidad y de amor colectivo frente al cosmopolitismo avasallador y modernista". ${ }^{52}$

La narrativa tradicionalista no parecía experimentar grandes transformaciones. Al menos en esos festejos reseñados, la dinámica reproducía los programas proyectados en las fiestas de la provincia de Buenos Aires. Para ese año, el núcleo de la Fiesta de la Tradición se continuó celebrando en la ciudad de La Plata. El decreto no pasaría inadvertido en la fiesta bonaerense que incorporó algunos elementos singulares en los actos desarrollados. En el diario platense El Día se anticipaba, desde una editorial, el sentido integral que adquiría la efeméride. ${ }^{53}$ En la capital bonaerense se congregaron más de mil gauchos que participaron en los desfiles. Las delegaciones que se enviaban desde distintos municipios de la provincia estuvieron complementadas por grupos llegados de la provincia de Santa Fe, Córdoba, San Juan y Tucumán. Allí radicaba la primera especificidad de la fiesta, los gauchos del interior escoltaron a los tradicionalistas de Buenos Aires, incorporándose en el desfile. Según la crónica periodística, entre todos los banderines que distinguían a las delegaciones, se dejaba ver uno que rezaba "Los gauchos de Perón". 54

La identificación con el presidente de la nación sería confirmada en el discurso del gobernador, Domingo Mercante, que se pronunció en la plaza central para concluir los festejos. En la primera parte de su discurso se ocupó de presentar la extensión de esa celebración abarcadora centrándose en elementos "comunes" de la historia nacional. El relato concluyó, en ese primer objetivo, con el llamado a priorizar lo autóctono en detrimento de lo extranjero remarcando que "Perón es el conductor de la gesta que nos emancipa definitivamente de lo foráneo." En una segunda parte, Mercante reconoció en el gaucho la referencia para esa emancipación. Se encaminó, entonces, a refutar las teorías que lo presentaban como un componente del pasado y lo habían sepultado en la historia. Según el Gobernador, el gaucho no estaba muerto, sino que había sido olvidado, desheredado. Desde esa interpretación se presentaba la exaltación de la obra impulsada a partir del golpe de Estado de junio de 1943, para finalizar: "El gaucho ha sido recuperado en este resurgimiento amanecido de la Tradición, por una institución rectora y por la mística suprema de la Revolución de Junio, cuyos postulados sociales amparan las reivindicaciones de los hijos del campo argentino." 55 En el discurso se condesaron dos elementos centrales: por un lado la identificación del gaucho con el peronismo, y por otro lado, la centralidad que ese sector político le otorgaba a su representación como trabajador rural contemporáneo.

\footnotetext{
52 Nativa revista mensual ilustrada, 30 de noviembre de 1948, p. 17.

${ }^{53}$ El Día, 10 de noviembre, p. 3.

${ }^{54}$ El Día, 11 de noviembre de 1948, p. 3.

${ }^{55}$ El Día, 11 de noviembre de 1948, p. 3.
} 
La nacionalización de la Fiesta de la Tradición evidenció dos procesos: en primer lugar, por las informaciones recogidas de los festejos en otras provincias, el decreto conllevaba la nacionalización del gaucho. Es decir, los pobladores rurales de diversas regiones del país eran clasificados como tales y su figura se difundía a partir de los desfiles, de las conferencias y de las manifestaciones artísticas. El carácter integral que adquirió la efeméride habría promovido, en primera instancia, la expansión del gaucho como arquetipo de la tradición nacional. En segundo lugar, la intervención política confirmó el progresivo camino de "peronización" de esa festividad. Las celebraciones poco a poco se fueron concentrando en los alrededores de la casa de Gobierno, en torno a la figura del presidente. La revista $P B T$, semanario adherido a las políticas peronistas, continuaba festejando, años después, la decisión de nacionalizar la fiesta y dedicaba su portada de noviembre a una ilustración de gauchos con la bandera argentina. El dibujo estaba acompañado por la leyenda: “Día de la Tradición: / la alborada que ilumina / a esta gran Nueva Argentina / la Argentina de Perón." 56

En 1949, a un año de la nacionalización de la fiesta, la editorial Olimpo editó una colección llamada "Alma Gaucha". En uno de sus libros, se publicó un poema gauchesco titulado "¡Viva el 1 de mayo! (a los obreros del mundo)". En los versos se destacaba la labor de Juan Perón y se crítica a los "detractores de las leyes del trabajo": "Abajo, mil veces abajo / Los mendicatos porrudos / ¡Viva Perón! los sesudos / Y el tañir de su badajo". En el texto se consolidaba la representación del gaucho trabajador redimido por Perón. La conclusión del poema ponía de relieve una perspectiva esperanzadora para los trabajadores en estrecha vinculación con la gestión peronista: "Marchamos de corazón / Ley y causa defendemos / A nuestro alcance tendremos / La palanca de Perón" ${ }^{57}$

\section{A modo de conclusión}

Las intervenciones aquí reseñadas confirmaban que hacia fines de la década del cuarenta, el gaucho se había consolidado como una figura representativa para la nación. Los próceres que eran evocados por la liturgia nacionalista, y que ostentaban una primacía contundente en términos de homenajes estatuarios, hallaban un complemento que se proponía como referencia no solo para los habitantes del campo argentino. Ese arquetipo, al que se pretendía eternizar en el bronce, evidenció una marcada labilidad en relación a la definición de sus características. Las fronteras para definir quién o qué era el gaucho o cuáles

\footnotetext{
${ }_{56}$ P.B.T. Alegre, política, deportiva, 6 de noviembre de 1953. La segunda época de la revista (había surgido en la primera década del siglo XX) fue publicada por la editorial Alea, propiedad de Carlos Aloé, gobernador de Buenos Aires durante la segunda presidencia de Perón.

${ }_{57}$ BIANCO, Francisco Luis Acosta García, Colección Alma Gaucha, Editorial Olimpo, Buenos Aires, 1949, pp. 7-9.
} 
eran sus atributos eran fácilmente franqueables. Sin embargo, una cualidad permaneció inmutable: su "modélico patriotismo". Ninguno de los discursos pronunciados en la legislatura bonaerense atentó contra la ligazón entre el gaucho y la argentinidad. La oficialización provincial por la ley de 1939 parecía haber consolidado su carácter de "símbolo nacional", como se corroboraba en las consideraciones de los funcionarios. De ese modo, se puso en juego la disputa partidaria por ese símbolo sin cuestionar su condición como tal.

La figura del gaucho como representación de la tradición nacional fue transitando un camino de cambios y adaptaciones de acuerdo a los vaivenes políticos que marcaron la vida institucional del país desde finales de la década del treinta. El tutelaje discutido que se analizó en este artículo daba cuenta de su condición de "herencia" para los sucesivos Gobiernos. En efecto, tanto en las presidencias de facto de la Revolución del 43 como durante la gestión de Juan Perón se usufructuó la legislación vigente sobre el gaucho y se profundizó su reivindicación con determinadas medidas. Las políticas del gaucho y de la tradición se insertaron, entonces, en una práctica amplia del peronismo que consistía en revestir, en términos partidarios, elementos culturales preexistentes.

En las disputas legislativas, la concreción o no del monumento quedó relegada ante una discusión más abstracta, simbólica. Allí, no solo se intentó dirimir cuál partido era el "más criollo", lo que estaba en cuestión era quién se consideraba como legítimo portador del legado tradicionalista. No se trataba de una cuestión menor porque el cultivo del gaucho y la tradición se entendía como un vector de aproximación hacia lo telúrico, lo autóctono y, en última instancia, hacia el "pueblo". A diferencia de los "prohombres" de la patria, el gaucho se vinculaba a los sectores populares de la campaña que habrían participado de las gestas patrióticas pero desde una posición de anonimato. Esa referencia como "hombre común" desplazó las alocuciones del debate legislativo hacia la historización de políticas $\mathrm{u}$ acciones partidaria en favor de los "gauchos". Enrolado en las revoluciones radicales o beneficiado por el estatuto del peón, las menciones pretendieron cristalizar una filiación pretérita y presente.

La nación ya no podía prescindir del gaucho en la continua -y complejatarea de cristalizar una identidad en común. Los legisladores bonaerenses evidenciaron que los partidos políticos tampoco. Con las readaptaciones necesarias del caso, ninguno estuvo dispuesto a resignar lo que simbolizaba su figura en orden a la "argentinidad". En ese sentido, la primera presidencia de Perón marcó un punto de inflexión que la distinguió de las anteriores. Con la nacionalización del Día de la Tradición, el peronismo le dio un tono integrador a la nueva efeméride nacional. Ante la propuesta radical para convertir en bronce las reivindicaciones al gaucho que se iban desarrollando desde tiempo atrás, el decreto del presidente en 1948 amplió el sentido de la fiesta y generó 
nuevas expresiones que se visibilizaban en distintos puntos del país. La apropiación peronista del gaucho se consolidó con la participación del mandatario y las celebraciones extendidas que ocupaban una semana en el calendario de festejos. La intensa identificación entre el gaucho y Perón se propagaría desde los discursos oficiales hasta el golpe de Estado de 1955. A partir de allí, comenzaría una nueva etapa para las diputas políticas marcada por los intentos de desarticular esa adhesión.

Buenos Aires, 9 de junio de 2016 